Original Research Article

\title{
Profile of vascular age and vascular response among elderly patients receiving antihypertensive therapy
}

\author{
Rama Mohan Pathapati ${ }^{1}$, Bhakthavatsala Reddy Chirra ${ }^{2}$, Parigala Madhavi ${ }^{1}$, \\ Tandayam Abhishek $^{1}$, B. L. Kudagi ${ }^{1}$, Madhavulu Buchineni ${ }^{1 *}$
}

${ }^{1}$ Department of Pharmacology,

${ }^{2}$ Department of Cardiology,

Narayana Medical College,

Nellore, Andhra Pradesh, India

Received: 28 August 2017

Accepted: 01 September 2017

\section{*Correspondence to:}

Dr. Madhavulu Buchineni, Email: madhavulu@gmail.com

Copyright: (C) the author(s), publisher and licensee Medip Academy. This is an openaccess article distributed under the terms of the Creative Commons Attribution NonCommercial License, which permits unrestricted noncommercial use, distribution, and reproduction in any medium, provided the original work is properly cited.

\begin{abstract}
Background: Normally the age of the arteries is same as that of the chronological age of the patient. In Hypertensive patients, complex interactions occur between prohypertensive factors, accelerating vascular age. Furthermore, prohypertensive factors to some extent are responsible for non-response to therapy at optimal doses. We assessed the correlation between response to therapy and vascular age in elderly hypertensives, in addition to vascular age and vascular response.

Methods: In this study, we analysed the clinical records of both male and female hypertensive patients above 60 years old. We collected the details of age, gender, body mass index, systolic blood pressure (treated and untreated), diabetes and smoking. Vascular age was calculated using a composite score of these six prohypertensive risk factors. Accelerated vascular age was then derived using the formula vascular age minus chronological age. The optimal vascular response was considered if the patient's therapeutic blood pressures are less than 140/ $90 \mathrm{mmHg}$.

Results: In the present study, data from 517 elderly hypertensive patients were analysed, the mean chronological age, vascular age and accelerated vascular age was $66.74 \pm 6.6,79.46 \pm 0.42$ and $13.46 \pm 6.08$ years. Only $32.7 \%$ were responders to anti-hypertensive treatment. The pattern of usage of anti-hypertensives in our patients is CCBs $39.10 \%$ followed by $30.90 \%$ ARB, $22.50 \%$ ACEI and $8.90 \%$ diuretics. The response in $20.50 \%$ of patients was achieved with a single drug, in $9.90 \%$ with two drugs and only in $2.30 \%$ of patients using three drugs. We found that $78.72 \%$ of our study population had vascular age more than ten years of chronological age, among them $66.6 \%$ between $60-69$ years of chronological age were non-responders. We found a significant correlation $(\mathrm{P}<0.05)$ between vascular age and non-response to treatment.

Conclusions: The majority $(98.6 \%)$ of our patients had vascular age more than 80 years due to various risk factors of cardio vascular disease. Nonresponsiveness to therapy showed a significant relationship with vascular age.
\end{abstract}

Keywords: Elderly hypertensives, Non-laboratory based vascular age, Response to antihypertensive therapy

\section{INTRODUCTION}

Hypertension is the largest contributor to the global burden of cardiovascular disease. In the elderly, the prevalence of hypertension is more than two times than in the young population. Therefore, hypertension is an ageing disorder. In hypertensive patients, complex interactions occur between prohypertensive factors, leading to accelerated vascular ageing. ${ }^{1}$ Patients who exhibit accelerated vascular ageing have an altered arterial function and structure, and such people often die of cardiovascular disease. ${ }^{1,2}$ The optimal control of blood pressure is considered low with advancing age in both men and women. ${ }^{3,4}$ Many reasons contribute uncontrolled BP includes nonadherence to medications, altered pharmacokinetics and dynamics, white coat hypertension, resistant hypertension, and 
patients with suboptimal treatment. ${ }^{5-7}$ Prohypertensive factors include gender, genetics, obesity, dyslipidemia, sedentary lifestyle, smoking, diabetes and advancing age. Studies have shown that coexistence of risk factors such as diabetes and smoking to some extent decrease the response. $^{8}$ The non-laboratory-based chart estimates vascular age using a composite score of six prohypertensive risk factors, such as age, sex, smoking status, body mass index, systolic blood pressure, and diabetes. ${ }^{9}$ This model, substitute's body-mass index for cholesterol and became a validated proxy to laboratorybased score for assessing the burden cardiovascular disease. ${ }^{10,11}$ However, its role in the management of hypertension has not been studied. We evaluated the profile of vascular age and vascular response among elderly hypertensive patients receiving therapy and explored the relationship between response to therapy and non-laboratory based vascular age in elderly hypertensives.

\section{METHODS}

In this retrospective study, we analysed the clinical records of elderly hypertensive outpatients above 60 years old. Data of patients with chronic Kidney Disease, endocrine disorders, congestive heart failure, arrhythmias, cardiomyopathy, coronary and cerebrovascular disease, and active autoimmune disease were not considered for analysis. Details of age, gender, body mass index (BMI), smoking, diabetes (DM), systolic blood pressure (SBP), Diastolic blood pressure (DBP), treatment history and number of antihypertensive medications were recorded in data collection forms. We calculated vascular age using non-laboratory based vascular risk chart (Figure 1) with age, gender, BMI, SBP (treated), DM and smoking. ${ }^{9}$

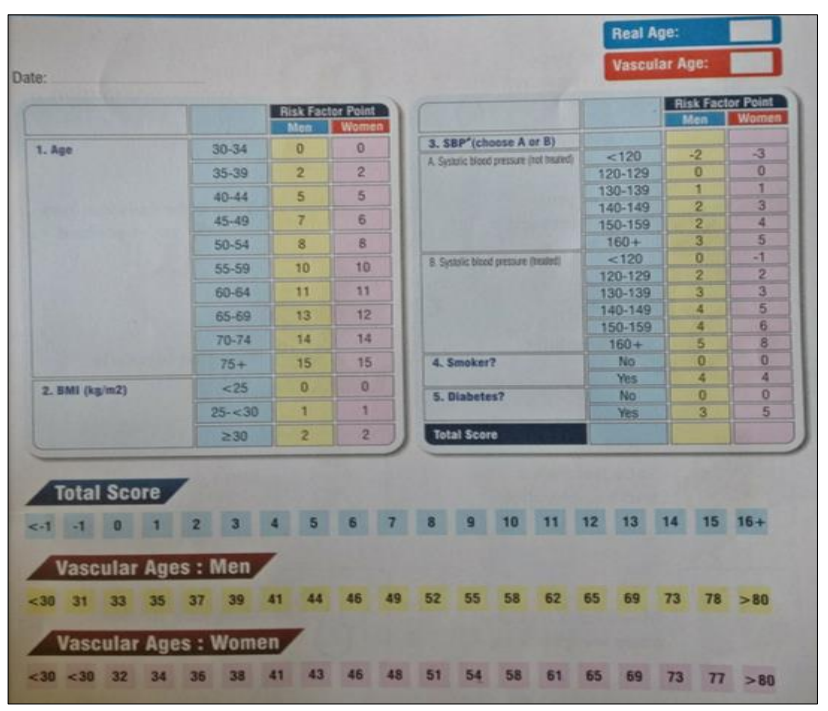

Figure 1: Non laboratory based vascular age calculator.

Accelerated vascular age was then derived using the formula vascular age minus chronological age and classified into three categories less than five years, 5-10 years and more than a ten years. We considered treatment as monotherapy, if the patients are receiving only one active ingredient and those taking one combination pill or two different pills as polytherapy. Responders were those with therapeutic blood pressures less than 140/90mmHg. ${ }^{12,13}$

\section{Statistical analysis}

Metric data was presented as the mean and standard deviation. Numbers and percentages were used to describe nominal and ordinal data. Statistical analysis was performed using SPSS version-11. To infer the parametric data we applied One way ANOVA and chi-square tests appropriately. We also performed Spearman correlation analysis between response to treatment with accelerated vascular age category and number of antihypertensive medications. A probability values less than 0.05 was considered statistically significant.

\section{RESULTS}

In the present study, data from 517 elderly hypertensive patients were analysed, the mean chronological age $66.74 \pm 6.6$ years, among them, 204/517 (39.8\%) were females, and $309 / 517(60.2 \%)$ were males. 308/517 $(59.6 \%)$ were diabetics, $205 / 517(39.7 \%)$ were smokers (Table 2). Mean duration of hypertension was $4.4 \pm 1.2$ years, and treatment duration was $2.8 \pm 1.1$ years. The BMI was $24.89 \pm 4.2 \mathrm{~kg} / \mathrm{m} 2$. The Mean SBP and DBP are $152.02 \pm 17.37$ and $94.14 \pm 11.12 \mathrm{mmHg}$ respectively (Table $1)$.

Table 1: Descriptive statistics of vascular risk factors.

\begin{tabular}{|c|c|c|c|c|}
\hline Variables & $\begin{array}{l}\text { Response } \\
(<140 / 90 \\
\text { mmHg) }\end{array}$ & $\mathbf{N}$ & Mean \pm SD & P value \\
\hline \multirow{3}{*}{$\begin{array}{l}\text { Age } \\
\text { (years) }\end{array}$} & No & 348 & $66.79 \pm 6.48$ & \multirow{3}{*}{0.79} \\
\hline & Yes & 169 & $66.63 \pm 6.86$ & \\
\hline & Total & 517 & $66.74 \pm 6.6$ & \\
\hline \multirow{3}{*}{$\begin{array}{l}\text { Vascular } \\
\text { age (years) }\end{array}$} & No & 348 & $79.97 \pm .40$ & \multirow{3}{*}{0.22} \\
\hline & Yes & 169 & $79.92 \pm .45$ & \\
\hline & Total & 517 & $79.46 \pm 0.42$ & \\
\hline \multirow{3}{*}{$\begin{array}{l}\text { Accelerated } \\
\text { vascular } \\
\text { Age (years) }\end{array}$} & No & 348 & $13.34 \pm 6.07$ & \multirow{3}{*}{0.73} \\
\hline & Yes & 169 & $13.54 \pm 6.13$ & \\
\hline & Total & 517 & $13.46 \pm 6.08$ & \\
\hline \multirow{3}{*}{$\begin{array}{l}\text { Body mass } \\
\text { index } \\
(\mathrm{kg} / \mathrm{m} 2)\end{array}$} & No & 348 & $25.05 \pm 4.21$ & \multirow{3}{*}{0.23} \\
\hline & Yes & 169 & $24.58 \pm 4.22$ & \\
\hline & Total & 517 & $24.89 \pm 4.2$ & \\
\hline \multirow{3}{*}{$\begin{array}{l}\text { Systolic } \\
\text { blood } \\
\text { pressure } \\
(\mathrm{mmHg})\end{array}$} & No & 348 & $159.22 \pm 16.74$ & \multirow{3}{*}{$<0.0001$} \\
\hline & Yes & 169 & $137.20 \pm 4.49$ & \\
\hline & Total & 517 & $152.02 \pm 17.37$ & \\
\hline \multirow{3}{*}{$\begin{array}{l}\text { Diastolic } \\
\text { blood } \\
\text { pressure } \\
(\mathrm{mmHg})\end{array}$} & No & 348 & $97.47 \pm 11.73$ & \multirow{3}{*}{$<0.0001$} \\
\hline & Yes & 169 & $87.28 \pm 5.08$ & \\
\hline & Total & 517 & $94.14 \pm 11.12$ & \\
\hline
\end{tabular}


The average vascular age of the patients was $79.46 \pm 0.42$ years. All our patients had higher vascular age than chronological age. The accelerated vascular age of these patients was $13.46 \pm 6.08$ years. Despite antihypertensive therapy, only $169 / 517(32.7 \%)$ of our patients had the optimal therapeutic blood pressure response $(<140 / 90 \mathrm{mmHg})$ and remaining $67.3 \%$ of our patients were nonresponders (Table 1).

When we assessed the number of antihypertensive drugs used by these patients, we found that $260 / 517(50 \%)$ were using a single drug, 188/517 (36\%) were using two and remaining 69/517 (13\%) were receiving three drugs. The order of usage of anti-hypertensives in our patients is CCBs $39.10 \%$ followed by $30.90 \%$ ARB, $22.50 \%$ ACEI and $8.90 \%$ diuretics. Among the responders, $20.50 \%$ achieved it with a single drug, $9.90 \%$ with two drugs and only $2.30 \%$ with three drugs (Table 2 ).
In our study, we found that $98.6 \%$ of our patients had vascular age more than 80 years due to various risk factors of cardio vascular disease. Upon classifying accelerated vascular age into three groups, we noticed that 59/517 $(11.4 \%)$ were in <5-year group, $51 / 517(9.9 \%)$ were in a 5-10-year group, and the majority $407 / 517$ (78.7\%) were in $>10$ years group.

Among the patients who had $>10$ years of accelerated vascular age, $70.8 \%$ were between $60-69$ years. The majority (48.20\%) of non-responders were between 60-69 years, males $(38.20 \%)$, people with diabetes $(42.20 \%)$, non-smokers $(41.30 \%)$, with normal BMI $(32.30 \%)$ and had accelerated Vascular age $>10$ years $(52.40 \%)$. There was a significant correlation between response to therapy and vascular age estimated by using the composite score of prohypertensive factors $(\mathrm{P}<0.05)$ (Table 3$)$.

Table 2: Vascular response versus antihypertensive drugs

\begin{tabular}{|c|c|c|c|c|c|c|}
\hline & \multicolumn{6}{|c|}{ Response (<140/90 mmHg) } \\
\hline & & & No & Yes & Total & P value \\
\hline \multirow{8}{*}{ Drugs } & \multirow{2}{*}{ One } & $\mathrm{n}$ & 154 & 106 & 260 & \multirow{8}{*}{$<0.0001$} \\
\hline & & $\%$ of Total & $29.80 \%$ & $20.50 \%$ & $50.30 \%$ & \\
\hline & \multirow{2}{*}{ Two } & $\mathrm{n}$ & 137 & 51 & 188 & \\
\hline & & $\%$ of Total & $26.50 \%$ & $9.90 \%$ & $36.40 \%$ & \\
\hline & \multirow{2}{*}{ Three } & $\mathrm{n}$ & 57 & 12 & 69 & \\
\hline & & $\%$ of Total & $11.00 \%$ & $2.30 \%$ & $13.30 \%$ & \\
\hline & \multirow{2}{*}{ Total } & $\mathrm{n}$ & 348 & 169 & 517 & \\
\hline & & $\%$ of Total & $67.30 \%$ & $32.70 \%$ & $100.00 \%$ & \\
\hline \multirow{6}{*}{$\begin{array}{l}\text { Calcium channel } \\
\text { blocker }\end{array}$} & \multirow{2}{*}{ No } & $\mathrm{n}$ & 206 & 108 & 314 & \multirow{6}{*}{0.33} \\
\hline & & $\%$ of Total & $39.90 \%$ & $20.90 \%$ & $60.90 \%$ & \\
\hline & \multirow{2}{*}{ Yes } & $\mathrm{n}$ & 141 & 61 & 202 & \\
\hline & & $\%$ of Total & $27.30 \%$ & $11.80 \%$ & $39.10 \%$ & \\
\hline & \multirow{2}{*}{ Total } & $\mathrm{n}$ & 347 & 169 & 516 & \\
\hline & & $\%$ of Total & $67.20 \%$ & $32.80 \%$ & $100.00 \%$ & \\
\hline \multirow{6}{*}{$\begin{array}{l}\text { Angiotensin converting } \\
\text { enzyme inhibitor }\end{array}$} & \multirow{2}{*}{ No } & $\mathrm{n}$ & 266 & 134 & 400 & \multirow{6}{*}{0.57} \\
\hline & & $\%$ of Total & $51.60 \%$ & $26.00 \%$ & $77.50 \%$ & \\
\hline & \multirow{2}{*}{ Yes } & $\mathrm{n}$ & 81 & 35 & 116 & \\
\hline & & $\%$ of Total & $15.70 \%$ & $6.80 \%$ & $22.50 \%$ & \\
\hline & \multirow{2}{*}{ Total } & $\mathrm{n}$ & 347 & 169 & 516 & \\
\hline & & $\%$ of Total & $67.20 \%$ & $32.80 \%$ & $100.00 \%$ & \\
\hline \multirow{6}{*}{$\begin{array}{l}\text { Angiotensin receptor } \\
\text { blocker }\end{array}$} & \multirow{2}{*}{ No } & $\mathrm{n}$ & 227 & 130 & 357 & \multirow{6}{*}{0.008} \\
\hline & & $\%$ of Total & $43.90 \%$ & $25.10 \%$ & $69.10 \%$ & \\
\hline & \multirow{2}{*}{ Yes } & $\mathrm{n}$ & 121 & 39 & 160 & \\
\hline & & $\%$ of Total & $23.40 \%$ & $7.50 \%$ & $30.90 \%$ & \\
\hline & \multirow{2}{*}{ Total } & $\mathrm{n}$ & 348 & 169 & 517 & \\
\hline & & $\%$ of Total & $67.30 \%$ & $32.70 \%$ & $100.00 \%$ & \\
\hline \multirow{6}{*}{ Diuretic } & \multirow{2}{*}{ No } & $\mathrm{n}$ & 315 & 156 & 471 & \multirow{6}{*}{0.62} \\
\hline & & $\%$ of Total & $60.90 \%$ & $30.20 \%$ & $91.10 \%$ & \\
\hline & Yes & $\mathrm{n}$ & 33 & 13 & 46 & \\
\hline & Yes & $\%$ of Total & $6.40 \%$ & $2.50 \%$ & $8.90 \%$ & \\
\hline & \multirow{2}{*}{ Total } & $\mathrm{n}$ & 348 & 169 & 517 & \\
\hline & & $\%$ of Total & $67.30 \%$ & $32.70 \%$ & $100.00 \%$ & \\
\hline
\end{tabular}


Table 3: Vascular response versus vascular risk factors.

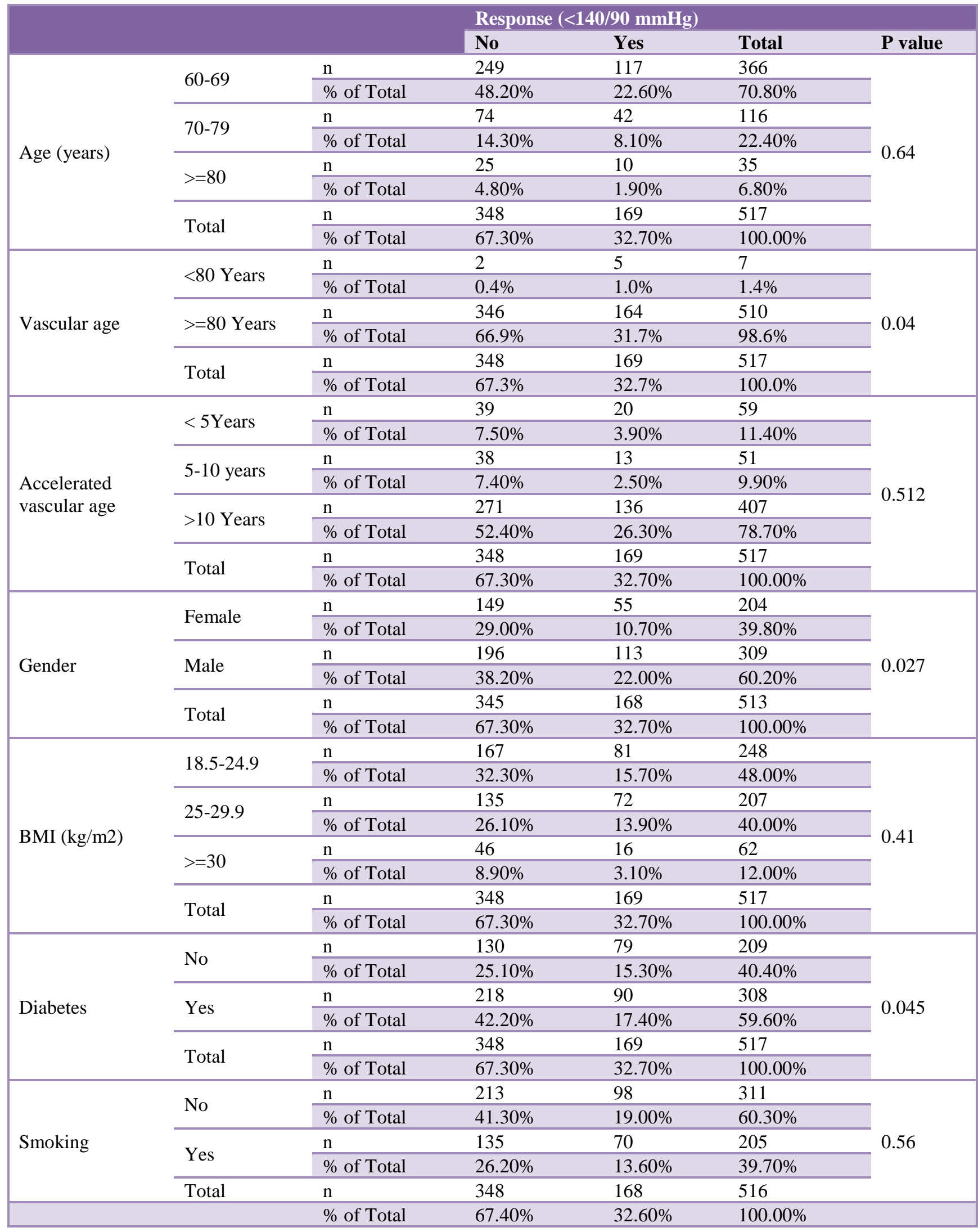


to anti-hypertensive treatment. Older persons are known to have the lowest rates of blood pressure control. ${ }^{14}$ Factors such as poor adherence to prescription, inadequate doses or inappropriate combinations, polypharmacy, an altered pharmacokinetic and pharmacodynamic states, side effects from medications, and the high cost of drugs and use of non-steroidal anti-inflammatory drugs could have contributed to such a nonresponse. ${ }^{5-7}$ There can also falsely elevated blood pressure levels due to inappropriate blood pressure recording-technique, noisy room, and nonvalidated instruments. ${ }^{15}$ Only a small percentage $(8.90 \%)$ of our patients were prescribed of diuretics, and this could be one of the possible reasons for low response rates in our study populations.

Accelerated ageing of arteries is due to coexistence of risk factors such as older age, smoking, BMI as an index by obesity, age, and diabetes. Other potential proinflammatory conditions, such as activation of the sympathetic nervous system, ageing, elevated aldosterone, involvement of oxidative stress and endothelial dysfunction could also contribute to hypertension. Risk factors increase arterial stiffness via alters neurohormonal related pathways and promotes non-responsiveness to therapy. ${ }^{16-18} \mathrm{We}$ explored whether early vascular ageing as assessed by nonlaboratory based vascular age calculator can predict non-response to anti-hypertensive treatment, and found a significant correlation between vascular age and nonresponse to hypertension treatment. Contrarily, Brown MJ et al, stated that presence of risk factors by themselves does not blunt the target response to therapy in hypertensive patients. ${ }^{8}$

\section{Limitations}

Sex-specific NLB vascular age algorithm is originally developed to assess general CVD risk and risk of individual CVD events. Its utility in response to hypertensive treatment remains to be validated. So Carefulness has to be implemented while interpreting our study results. Data regarding the non-adherence to treatment was not available. The highest vascular age according to nonlaboratory based vascular risk chart is more than 80 ; we rounded it to 80 years for calculation of approximated accelerated vascular age.

\section{CONCLUSION}

The majority $(98.6 \%)$ of our patients had vascular age more than 80 years due to various risk factors of cardio vascular disease. Only $32.7 \%$ were responders to antihypertensive therapy. Non-responsiveness to therapy showed a significant relationship with vascular age. Further studies are needed to assess the utility of this nonlaboratory based vascular age calculator in predicting the response to antihypertensive response at optimal doses.

Funding: No funding sources Conflict of interest: None declared
Ethical approval: The study was approved by the Institutional Ethics Committee

\section{REFERENCES}

1. Harvey A, Montezano AC, Lopes RA, Rios F, Touyz RM. Vascular Fibrosis in Aging and Hypertension: Molecular Mechanisms and Clinical Implications. The Canadian Journal of Cardiology. 2016;32(5):659-68.

2. Baker PB, Baba N, Boesel CP. Cardiovascular abnormalities in progeria. Case report and review of the literature. Archives of Pathology \& Laboratory Medicine. 1981;105(7):384-6.

3. Franklin SS, Jacobs MJ, Wong ND, Gilbert J, Lapuerta P. Predominance of isolated systolic hypertension among middle-aged and elderly US hypertensives. Hypertension. 2001;37(3):869-74.

4. Lloyd-Jones DM, Evans JC, Levy D. Hypertension in adults across the age spectrum: Current outcomes and control in the community. Jama. 2005;294(4):466-72.

5. Alderman MH. Resistant hypertension: a clinical syndrome in search of a definition. American journal of hypertension. 2008;21(9):965-6.

6. Calhoun DA, Jones D, Textor S, Goff DC, Murphy TP, Toto RD, et al. Resistant hypertension: diagnosis, evaluation, and treatment. A scientific statement from the American Heart Association Professional Education Committee of the Council for High Blood Pressure Research. Hypertension. 2008;51(6):140319.

7. Cunningham G, Dodd TR, Grant DJ, Mcmurdo ME, Michael R, Richards E. Drug-related problems in elderly patients admitted to Tayside hospitals, methods for prevention and subsequent reassessment. Age and ageing. 1997;26(5):375-82.

8. Brown MJ, Castaigne A, de Leeuw PW, Mancia G, Palmer CR, Rosenthal T, et al. Influence of Diabetes and Type of Hypertension on Response to Antihypertensive Treatment. 2000;35(5):1038-42.

9. D'Agostino RB, Vasan RS, Pencina MJ, Wolf PA, Cobain M, Massaro JM, et al. General cardiovascular risk profile for use in primary care: the Framingham Heart Study. Circulation. 2008;117(6):743-53.

10. Gaziano TA, Young CR, Fitzmaurice G, Atwood S, Gaziano JM. Laboratory-based versus non-laboratorybased method for assessment of cardiovascular disease risk: the NHANES I Follow-up Study cohort. The Lancet. 2008 Mar 21;371(9616):923-31.

11. Pandya A, Weinstein MC, Gaziano TA. A Comparative Assessment of Non-Laboratory-Based versus Commonly Used Laboratory-Based Cardiovascular Disease Risk Scores in the NHANES III Population. PLoS ONE. 2011;6(5).

12. Aronow WS. Treatment of systemic hypertension. American Journal of Cardiovascular Disease. 2012;2(3):160-70.

13. Chobanian AV, Bakris GL, Black HR, Cushman WC, Green LA, Izzo JL, et al. The seventh report of the joint national committee on prevention, detection, 
evaluation, and treatment of high blood pressure: the JNC 7 report. Jama. 2003;289(19):2560-71.

14. Lloyd-Jones DM, Evans JC, Levy D. Hypertension in adults across the age spectrum: current outcomes and control in the community. Jama. 2005 Jul 27;294(4):466-72.

15. Sarafidis PA, Bakris GL. State of hypertension management in the United States: confluence of risk factors and the prevalence of resistant hypertension. The Journal of Clinical Hypertension. 2008;10(2):130-9.

16. Redfield MM, Jacobsen SJ, Borlaug BA, Rodeheffer RJ, Kass DA. Age- and gender-related ventricularvascular stiffening: a community-based study. Circulation. 2005 Oct 11;112(15):2254-62.
17. Mahmud A, Wadi H, Feely J, Silke B. Cigarette smoking reduces blood pressure response to antihypertensive treatment in newly diagnosed hypertensive patients. Journal of hypertension. 2015 Jun;33(11):e94.

18. Heineke J, Molkentin JD. Regulation of cardiac hypertrophy by intracellular signalling pathways. Nature reviews Molecular cell biology. 2006 Aug;7(8):589-600.

Cite this article as: Pathapati RM, Chirra BR,

Madhavi P, Tandayam A, Kudagi BL, Buchineni M.

Profile of vascular age and vascular response among elderly patients receiving antihypertensive therapy. Int J Basic Clin Pharmacol 2017;6:2328-33. 